\title{
Journal of Food and Dairy Sciences
}

Journal homepage: www.jfds.mans.edu.eg

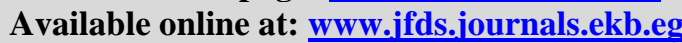

\section{Comparative Study Between Virgin Coconut Oil and Omeprazole Drug on Ulcerative Colitis in Experimental Rats}

\author{
Abd El-Ghany, M. A.*; Afaf-Haniem M. Ramadan; Rasha M. Nagib and Fayza M. EL-Azaly \\ Cross Mark
}

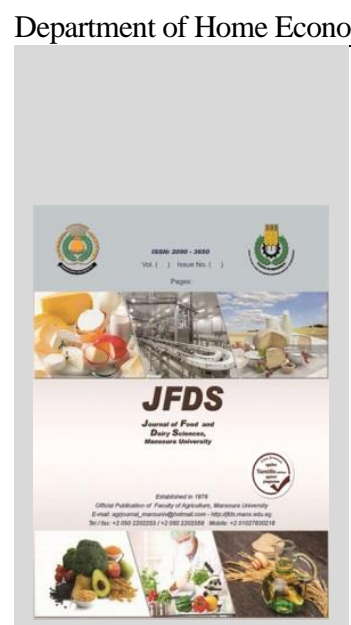

$\frac{\text { mics, Faculty of Specific Education,Mansoura University, Egypt }}{\text { ABSTRACT }}$

This study aims to identify the curative effect of virgin coconut oil on ulcerative colitis(UC),the present study was carried (24) adult albino male rats Sprague -Dawley strain weighting $180 \pm 10 \mathrm{~g}$ were classified into four groups, (6 rats each) the first group rats were fed on basal diet only control negative(ve) group and three rat groups were injured of ulcerative colitis by intra colonic administration of acetic acid $4 \%$ given rectally by single dose ( $1 \mathrm{ml} / \mathrm{rat}$ ) and reclassified into control positive (+ve) group (fed on basal diet only), group treated with $(20 \mathrm{mg} / \mathrm{kg} \mathrm{b.w})$ of omeprazole drug and group treated with $(2 \mathrm{ml}$ per/ rat) daily of virgin coconut oil . The results revealed that, the control (+ve) group showed a significant decrease in final weight(FW), weight gain(WG) feed efficiency ratio (FER), organs weight of heart, kidney, and liver, catalase (CAT), superoxide dismutase (SOD), glutathione reduced (GSH), Glutathione reductase (GSR),Glutathione peroxidase (GPx), glutathione-S-transferees (GST) and significant increase in malondialdehyde (MDA), hydrogen peroxide $\left(\mathrm{H}_{2} \mathrm{O}_{2}\right)$, C-reactive protein (CRP), interleukin-6 (IL-K) and prostaglandin (PG2) compared with control (- ve) group. The virgin coconut oil group showed a significant increase in (FW),(WG),(FI),(FER),organ stomach,(CAT),(SOD),(GSH), (GSR (GPx), (GST) but significant decrease in (MDA), $\left(\mathrm{H}_{2} \mathrm{O}_{2}\right),(\mathrm{CRP}),(\mathrm{ILK}),(\mathrm{PG} 2)$ compared with control (+ve) group . the study clearly showed that consumption virgin coconut oil has a role in treating rats with acetic acid-induced ulcerative colitis. It can be recommended that virgin coconut oil should be consumed daily to reduce the incidence of ulcerative colitis.

Keywords: virgin coconut oil, acetic acid, ulcerative colitis, experimental rat.

\section{INTRODUCTION}

Virgin Coconut Oil (VCO) is considered a medicinal functional food in the many popular countries that cultivate it. It is an unrefined oil extracted from the fresh and ripe coconut fruit (Cocos nucifera $L$ ) and is extracted manually or mechanically using special oil extraction machines, with Or without the use of heat and without chemical bleaching and deodorization (Marina et al. 2009).Coconut contains a high percentage of dietary fiber, which studies indicate absolute importance for the colon. Reports confirm that coconut oil is not considered one of the causes of obesity, as it does not accumulate in fatty tissues and is therefore It is not considered a reason for weight gain. It tends to increase HDL (Assuncao et al., 2009). Recent studies have shown the importance of coconut oil that it has phenol-dependent antioxidant properties for VCO in animal models (Seneviratne et al., 2009). Coconut oil contains a high percentage of saturated fats, and thus, this may lead to an increase in the level of cholesterol in the blood, but studies have indicated its importance and its confrontation with cardiac risks. thus, a systematic study was conducted to clarify the effect of coconut oil intake on cardiovascular attacks and increased blood lipids by comparing it with other cooking oils using data from clinical trials (Neelakantan et al., 2020). As a result of the increase in coconut oil and the popularity of it in the past decades, its importance in improving the metabolism process. Anti-oxidant, antiinflammatory and anti-diabetic. (Malaeb and Spoke et al.,
2020) Coconut oil has a significant lowering effect by stimulation in cholesterol. The pathophysiology of ulcerative colitis entails, along with a limited set of therapeutic qualities that distinguish it and make it a natural product alternative to treatments. It is suggested that coconut oil contains medium-chain fatty acids because it has an effect on the symptoms of colic and ulcerative colitis of patients by modifying inflammatory responses in diseased mice (Chandra 2013). Coconut oil (CO) has garnered interest in Western medicine due to its promising therapeutic effect in treating Alzheimer's disease as well as combating neurodegeneration caused by induced oxidative chains. (Odubanjo et al., 2020).

Ulcerative colitis (UC) is a chronic disease that affects the large intestine or colon and causes ulceration and inflammation of the mucous membrane lining the large intestine and rectum (Xavier and Podolsky, 2007). It can occur in any area of the large intestine, although complementary colitis may affect certain parts of some patients with UC, the immune system sends false signals and colon gases appear (Itzkowitz and Yio 2004). Several types of medications are available as amino salicylates. It is a common disease that affects millions of individuals all over the world and can be considered one of the most common diseases in the world. (Awaad et al., 2013).

Omeprazole is widely used to treat disorders of the digestive system However, in the long run use of OME increases the risk of stomach cancer. We aimed to characterize the pharmacological effects of OME and 
correlate its adverse effects and toxicological risks with mechanisms of genetic instability and cancer based on the database reports (Marcia et al., 2020).

The laboratory results revealed that omeprazole has antioxidant and anti-inflammatory properties. There was also a significant amelioration in body weight percentage, colonic, ulcer degree, and biochemical analyzes in the omeprazole treated group comparison to the colitis group, which had prevenient anti-inflammatory and antioxidant efficacy Ittiyavirah and Shenika (2014).

This work is designed to use virgin coconut oil in diets to treat the side effects of acetic acid-induced ulcerative colitis in rats.

\section{MATERIALS AND METHODS}

\section{A - Materials}

1-Acetic acid and distilled water were purchased from ElGomhouria company for trading chemicals and medical appliance, Dakahlia branches, El Mansoura, Egypt.

2-Omeprazol was obtained from Egyphar Company, Obour City. Each tablets contains $20 \mathrm{mg}$ of Omeprazol .The animal dose $(20 \mathrm{mg} / \mathrm{kg})$ adjustable to anterior of paper as listed by (Raeesi et al .,2019).

3-Coconut fruit were purchased from the local market in Mansoura city, Egypt. Virgin Coconut oil is given (2 ml per rat). (Meng et al., 2019).

\section{4-Experimental animals:}

This work was carried on 24 healthy adult albino male rats of Sprague-Dawley strain, purchased from the Agricultural Research Center, Giza, Egypt weighted180 \pm 10 g.

\section{B- Methods:}

\section{1-Preparation of virgin coconut oil (VCO):}

The VCO had been prepared using Divina and Keith (2006) method as follows: Freshly ripened coconuts were peeled by hand and coconut pulp using a coconut slicing machine. then the milk was extracted from the hand grated coconut pulp. The milk extracted from the pulp is set aside, and then the coconut residue sepal is taken for the second extraction process. The sepal was mixed with distilled water in a ratio of 2 sepal: 1 water. The mixture was pressed to obtain a second milk extract. The milk obtained from the first and second extractions was mixed by stirring vigorously for 10 minutes. Then it was cooled in the refrigerator for 3 hours and left to stand, then separate the coconut cream (the fatty part) from the skimmed coconut milk (the water part) by stripping the cream on top. Put coconut cream in a beaker and put it in a water bath at $50^{\circ} \mathrm{C}$ for 2.5 hours, to isolate coconut protein (latex) from coconut oil. drain the oil from the latex so that it is separated from it using a muslin cloth. Coconut oil is incubated at $50^{\circ} \mathrm{C}$ for 12 hours to remove all remaining moisture. The extracted oil is stored in a dark place at room temperature. The final result oil was term VCO.

\section{2-Grouping of experimental rats}

After the adaptation were rats were classified into four groups (6 rats each). Rat were kept under surveillance for seven days for adaptation and fed on basal diet and water was given ad libitum access. The basal diet was prepared according to NRC (1992). The experiment lasted for 60 days, and the rats were randomly classified into control (ve) group fed basal diet only and three ulcerative colitis groups by intra colonic administration of acetic acid $4 \%$ given rectally by single dose $(1 \mathrm{ml} / \mathrm{rat})$ using $8-\mathrm{cm}$ - soft $6 \mathrm{~F}$ pediatric catheter and reclassified into control (+ve), and treated group by Omeprazole drug (20 mg/kg b.w) and treated group by coconut oil ( $2 \mathrm{ml}$ per rat) by stomach tube. 3-Induction of ulcerative colitis by acetic acid

Before infection with ulcerative colitis, rats are fasted for 24 hours. Ulcerative colitis was induced in rats by intrarectal (IR) administration of $1 \mathrm{ml}$, of acetic acid $4 \%$ in normal saline solution under ether anesthesia. A $1 \mathrm{~mL} \mathrm{4 \%} \mathrm{AA}$ solution was instilled into the rectum into the colon slowly by a soft, $8 \mathrm{~cm}$ diameter polypropylene $6 \mathrm{~F}$ catheter lubricated with gel $2 \mathrm{~mm}$ in diameter through the anal canal into the colon. Rats are placed in a horizontal position to prevent the solution from escaping for 30 seconds (Elife et al., 2010).

4-Calculation of some Nutritional Parameters:

Nutrition performance and physical recorded and tracked by recording daily food intake, body weight gain and feeding efficiency ratio (FER) as average daily body weight gain divided growth were by average daily food intake. according to (Chapman et al.,1959) Rats were sacrificed after 60 days. Relative organs weight = organ weight $(\mathrm{g}) /$ Final body weight $(\mathrm{g}) \times 100$. Blood and livers were collected for biochemical analysis

\section{Biochemical analysis}

When experimentation period was over, animals in all groups were anesthetized by diethyl ether. Blood samples were taken from the eye of rats using heparin capillary tubes, then the serum were obtained after centrifugation at 3000 rpm for 10 minutes in a centrifugal machine(Xiang tian SH120B). Samples were preserved in a deep freezer at $-20{ }^{\circ} \mathrm{C}$ until used for various biochemical analyzes. Serum (CRP, IL-6, PG2) levels were tested, using laboratory kits from El Gomhouria company in Mansoura city, Dakahlia Governorate, Egypt; as the following:

5-Anti-inflammation (CRP, IL-6 and PG2) C- reactive protein level (CRP): was measured depending on the method of Vaishnavi (1993). While interleukin-6 was assessed and quantified according to the method of (Calabrese and John 2014), PG2 prostaglandins was measured depending on the method of (Robert .,1979)

After the completion of the experiment period, the rats were slaughtered; the abdomen was cut longitudinally and cleaned with saline solution to be prepared for the evaluation of antioxidants and free radical in the abdominal tissues.

6-Serum Antioxidant enzymes: Confirmation of glutathione peroxides (GPx) activity according to (Paglia and Valentine 1967), Confirmation of glutathione reduced (GSH) activity according to (Beutler et al .,1963) ,Confirmation of glutathione reductase (GSR) activity according to (Goldberg and Spooner 1983),Confirmation of glutathione-S- transferees (GST) activity according to (Habig and Jakoby 1974 ). While Confirmation of superoxide dismutase SOD activity according to (Nishikimi et al., 1972). Enzymatic CAT activity was measured according to (Aebi 1984).

7- Blood: Malondialdehyde (MDA) measured calorimetrically according to the method of (Satoh 1978)while $\mathrm{H}_{2} \mathrm{O}_{2}$ hydrogen peroxide was measured depending on the method according to (Aebi 1984).)

\section{8-Statistical data analysis:}

All tests were accomplish using computer package of the statistical analysis program (SPSS, version 24, 2016), the 
collected data were presented as means \pm standard deviations (means \pm S.D), statistically analyzed using one way analysis of Variance (ANOVA), and the means between groups were compared by least significant difference (LSD) statistic test, according to (Artmitage and Berry 1987).

\section{RESULTS AND DISSCUSION}

Data in Table (1) showed that final weight, body weight gain, body weight gain $\%$ and food efficiency ratio (FER) were significantly lower in ulcerative colitis rat than in the negative group and showed non- significant difference in food intake. Virgin Coconut oil treated group (VCO) showed significant increase in final weight and feed efficiency ratio (FER), however explained non- significant difference in body weight gain $\%$ and food intake compared with control (+ve) group. while showed significant decrease in body weight gain and feed efficiency ratio (FER) whoever appeared non- significant difference in final weight, and food intake in compared with control omeprazole drug group. These results in agreement, with (St-Onge et al., 2003) who showed that the coconut oil enhances metabolism because it contains of medium-chain triglycerides (MCT). thus the VCO role in weight loss is also consistent with (Famurewa et al., 2018) who said that VCO addition for 14 days induced insignificant body weight change in rats. And leads a weight-loss intervention.

Table 1. Nutritional indicators of negative control (-ve) group, untreated ulcerative colitis rat (+ve) group and treated by Omeprazole drug or Virgin Coconut oil.

\begin{tabular}{|c|c|c|c|c|c|c|}
\hline $\begin{array}{ll} & \text { Variable } \\
\text { Groups } & \\
\end{array}$ & Initial weight (gm) & Final weight (gm) & Weight gain (gm) & Weight gain\% & Food intake (gm) & FER \\
\hline Control (-ve) & $\begin{array}{c}\mathrm{a} \\
187.00 \pm 9.63\end{array}$ & $\begin{array}{c}\mathrm{a} \\
314.50 \pm 11.26 \\
\end{array}$ & $\begin{array}{c}\mathrm{a} \\
127.50 \pm 17.65 \\
\end{array}$ & $\begin{array}{c}\mathrm{a} \\
68.67 \pm 12.60\end{array}$ & $\begin{array}{c}\mathrm{a} \\
17.49 \pm 0.04\end{array}$ & $\begin{array}{c}\mathrm{a} \\
0.122 \pm 0.02\end{array}$ \\
\hline Control(+ve) & $\begin{array}{c}\mathrm{a} \\
184.00 \pm 9.00 \\
\end{array}$ & $\begin{array}{c}c \\
253.83 \pm 20.54 \\
\end{array}$ & $\begin{array}{c}\mathrm{d} \\
69.83 \pm 19.32 \\
\end{array}$ & $\begin{array}{c}\mathrm{b} \\
38.06 \pm 11.04 \\
\end{array}$ & $\begin{array}{c}\mathrm{a} \\
18.48 \pm 0.07 \\
\end{array}$ & $\begin{array}{c}\mathrm{d} \\
0.063 \pm 0.02 \\
\end{array}$ \\
\hline Omeprazole drug & $\begin{array}{c}\mathrm{ab} \\
178.00 \pm 7.18 \\
\end{array}$ & $\begin{array}{c}\mathrm{b} \\
281.67 \pm 16.84 \\
\end{array}$ & $\begin{array}{c}\mathrm{b} \\
103.67 \pm 21.75 \\
\end{array}$ & $\begin{array}{c}\mathrm{a} \\
58.63 \pm 14.14 \\
\end{array}$ & $\begin{array}{c}\mathrm{a} \\
17.88 \pm 0.01\end{array}$ & $\begin{array}{c}\mathrm{a} \\
0.097 \pm 0.02 \\
\end{array}$ \\
\hline Virgin Coconut oil & $\begin{array}{c}\mathrm{a} \\
184.50 \pm 9.42\end{array}$ & $\begin{array}{c}\mathrm{b} \\
273.17 \pm 14.26\end{array}$ & $\begin{array}{c}c \\
88.67 \pm 19.35\end{array}$ & $\begin{array}{c}\mathrm{b} \\
48.48 \pm 12.60\end{array}$ & $\begin{array}{c}\mathrm{a} \\
17.88 \pm 0.03\end{array}$ & $\begin{array}{c}\mathrm{b} \\
0.083 \pm 0.02\end{array}$ \\
\hline
\end{tabular}

Mean values in each column having different subscript $(a, b, c$ and $d)$ are significantly at $(\mathbf{P}<0.05)$.

Data in Table (2) showed significant increase in heart, kidney, and liver in ulcerative colitis rat(v+) group, but appeared non- significant difference in stomach weight compared with negative control. Virgin Coconut oil treated group (VCO) showed that significant decrease in organs weight stomach, heart, kidney, and liver in compared with control (+ve) group, while showed non-significant deference in these organs compared with omeprazole drug group.

Table 2. Some organs body weight of negative control (ve) group, untreated ulcerative colitis rat (+ve) group and treated by Omeprazole drug or Virgin Coconut oil.

\begin{tabular}{lcccc}
\hline Group & $\begin{array}{c}\text { Variables } \\
\text { (gm) }\end{array}$ & $\begin{array}{c}\text { Heart } \\
(\mathbf{g m})\end{array}$ & $\begin{array}{c}\text { Kidney } \\
(\mathbf{g m})\end{array}$ & $\begin{array}{c}\text { Liver } \\
(\mathbf{g m})\end{array}$ \\
\hline \multirow{3}{*}{ Control (-ve) } & $\mathrm{a}$ & $\mathrm{b}$ & $\mathrm{b}$ & $\mathrm{b}$ \\
& 0.91 & 0.34 & 0.87 & 3.23 \\
& \pm 0.02 & \pm 0.03 & \pm 0.04 & \pm 0.20 \\
\hline \multirow{3}{*}{ Control(+ve) } & $\mathrm{a}$ & $\mathrm{a}$ & $\mathrm{a}$ & $\mathrm{a}$ \\
& 0.93 & 0.47 & 1.34 & 5.01 \\
\hline \multirow{2}{*}{ Omeprazole } & \pm 0.07 & \pm 0.02 & \pm 0.14 & \pm 0.10 \\
drug & 0.66 & 0.33 & 0.83 & 3.27 \\
& \pm 0.14 & \pm 0.07 & \pm 0.08 & \pm 0.64 \\
\hline \multirow{2}{*}{ Virgin Coconut } & $\mathrm{b}$ & $\mathrm{b}$ & $\mathrm{b}$ & $\mathrm{b}$ \\
oil & 0.68 & 0.36 & 0.90 & 3.33 \\
& \pm 0.07 & \pm 0.05 & \pm 0.10 & \pm 0.49
\end{tabular}

Mean values in each column having different subscript (a, b, c and d) are significantly at $(\mathbf{P}<0.05)$.

These results in agreement with Asagba et al., (2008) who said that virgin coconut oil supplementation gained a general increase in organ weight in mice but this was only significant $(\mathrm{p}<0.05)$ increase in liver weight when compared to the healthy group. The significant increase in liver weight may be attributed to the liver's ability to rapidly form cholesterol. (Garg and Blake 1997).
Data in Table (3) showed significant increase in malondialdehyde (MDA) level and, hydrogen peroxide $\left(\mathrm{H}_{2} \mathrm{O}_{2}\right)$ in ulcerative colitis rat in comparison with the negative control group. Virgin Coconut oil treated group (VCO) showed significant lowering in malondialdehyde (MDA) level and, hydrogen peroxide $\left(\mathrm{H}_{2} \mathrm{O}_{2}\right)$ in comparison with positive control (+ve) group, while showed nonsignificant difference in (MDA) and $\left(\mathrm{H}_{2} \mathrm{O}_{2}\right)$ compared with omeprazole drug group.

Table 3. (MDA) and $\left(\mathrm{H}_{2} \mathrm{O}_{2}\right)$ in tissue of negative control (-ve) group, untreated ulcerative colitis rat (+ve) group and treated by Omeprazole drug or Virgin Coconut oil.

\begin{tabular}{lcccc}
\hline $\begin{array}{c}\text { Groups } \\
\text { variable }\end{array}$ & $\begin{array}{c}\text { Control } \\
(-\mathbf{e})\end{array}$ & $\begin{array}{c}\text { Control } \\
(+\mathbf{+ v e})\end{array}$ & $\begin{array}{c}\text { Omeprazole } \\
\text { drug }\end{array}$ & $\begin{array}{c}\text { Virgin } \\
\text { Coconut oil }\end{array}$ \\
\hline $\mathrm{MDA}$ & $\mathrm{c}$ & $\mathrm{a}$ & $\mathrm{b}$ & $\mathrm{b}$ \\
$\mathrm{nmol} / \mathrm{g}$ & 1.29 & 15.27 & 6.31 & 7.22 \\
tissue & \pm 0.13 & \pm 0.80 & \pm 1.10 & \pm 1.01 \\
\hline $\mathrm{H}_{2} \mathrm{O}_{2}$ & $\mathrm{c}$ & $\mathrm{a}$ & $\mathrm{b}$ & $\mathrm{b}$ \\
$\mathrm{mM} / \mathrm{g}$ & 0.06 & 2.85 & 1.25 & 1.39 \\
tissue & \pm 0.01 & \pm 0.51 & \pm 0.45 & \pm 0.18 \\
\hline
\end{tabular}

Mean values in each column having different subscript $(a, b, c$ and $d)$ are significantly at $(\mathbf{P}<\mathbf{0 . 0 5})$ : Malondialdehyde (MDA) hydrogen peroxide $\left(\mathrm{H}_{2} \mathrm{O}_{2}\right)$.

These results were in agreement with(Zakaria et al., 2011) who reported that the virgin coconut oil is rich in polyphenols and these antioxidants may contribute to the increased levels of antioxidant enzymes, which subsequently reduce lipid peroxidation and inflammation (MDA and $\mathrm{H}_{2} \mathrm{O}_{2}$ ) in VCO-treated rat.(Arunima and Rajamohan 2013) who said that virgin coconut oil administration controlled oxidative stress, which shows by reducing the formation of lipid peroxidation and protein oxidation products such as malondialdehyde, hydroperoxides, denise syndrome and carbonyl protein in serum and tissues comparing to other oil-fed mice $(\mathrm{P}<0.05)$, 
this interesting excitement returns to the presence of large quantities of phenolic compounds in the VCO.It is distinguished by antioxidant property, which was affected by the deficiency of free radicals with ferulic and bcoumaric acids and other flavonoids that contribute to the antioxidant and pragmatic effects of the kidneys with the VCO polyphenol fraction in this study (Srivastava et al., 2016). Also (Famurewa et al., 2018) reported that the level of malondialdehyde (MDA), showed a lipid peroxidation marker, remarkably reduced activities of hepatic antioxidant enzymes-superoxide dismutase (SOD), catalase (CAT), and glutathione peroxidase (GPx) were markedly increased in VCO diet-fed rats.

Data in Table (4) showed significant decrease in CAT, SOD, GSH ,GSR, GPx and GST levels in ulcerative colitis rat comparing with the negative control group. Virgin Coconut oil treated group (VCO) appeared increased in CAT, SOD, GSH ,GSR, GPx and GST levels comparing with positive group, while showed non significant difference in SOD and GSH whoever found slightly increase in CAT and GST but significant decrease in GSR and GPx levels in compared with omeprazole drug group. Studies that are consistent indicates that the VCO exhibits a protective property against ethanol. The results also indicate a similar trend in cold stress ulcers; it also leads to an increase in the levels of GSH and a decrease in the levels of nitrite MDA, CAT, SOD and GP which showed that VCO demonstrated with its protective action in the ethanolinduction in rats (Meng et al., 2019). There is an raise in the levels of GSH and nitrite corresponding to the reduced in MDA, CAT, SOD and GP appearing by VCO Proposed that there is a strong link of its antiulcer activity with the free radical scavenging activity, similar to omeprazole drug (Biswas et al., 2003). VCO significantly increased superoxide dismutase activity compared to NS-treated mice. Moreover, epithelial tissue restoration and inflammatory cell reduction were greater in VCO treatment compared to omeprazole drug treated animals and control animals. VCO contains high unsaponifiable lipid components like vitamin $\mathrm{E}$ and polyphenols, tocopherols, $\beta$ carotene and phytosterol in stabilizing cell membranes by preventing alterations in membrane lipid polarity and fluidity (Jaarin et al., 2014).these organic acids are thought to have a synergistic effect on phenolic antioxidants so that they can increase their antioxidant activity (Septiana and Hidayah 2010). the ferulic acid found in the VCO was more potent as an antioxidant against LDL oxidation than ascorbic acid. It seems that VCO derives most of its effects from the freeradical scavenging and antioxidant properties of ferulic acid (Gastelluccio et al., 1996).

Table 4. Some antioxidant enzymes in tissue of negative control (-ve)group, untreated ulcerative colitis rat(+ve) group and treated by Omeprazole drug or Virgin Coconut oil.

\begin{tabular}{|c|c|c|c|c|c|c|}
\hline Variable & $\begin{array}{c}\text { CAT } \\
(\mathrm{u} / \mathrm{g}) \text { tissue }\end{array}$ & $\begin{array}{c}\text { SOD } \\
(\mathrm{u} / \mathrm{g}) \text { tissue }\end{array}$ & $\begin{array}{c}\text { GSH } \\
(\mathrm{mmol} / \mathrm{g}) \text { tissue }\end{array}$ & $\begin{array}{c}\text { GSR } \\
(\mathrm{u} / \mathrm{g}) \text { tissue }\end{array}$ & $\begin{array}{c}\text { GPx } \\
\text { (u/g) tissue }\end{array}$ & $\begin{array}{c}\text { GST } \\
(\mathrm{u} / \mathrm{g}) \text { tissue }\end{array}$ \\
\hline Control ( -ve) & $\begin{array}{c}\mathrm{a} \\
6.58 \pm 0.81\end{array}$ & $\begin{array}{c}\mathrm{a} \\
632.28 \pm 4.20\end{array}$ & $\begin{array}{c}\mathrm{a} \\
341.67 \pm 14.59\end{array}$ & $\begin{array}{c}\mathrm{a} \\
24.33 \pm 2.60\end{array}$ & $\begin{array}{c}\mathrm{a} \\
66.95 \pm 7.24\end{array}$ & $\begin{array}{c}\mathrm{a} \\
312.67 \pm 7.55\end{array}$ \\
\hline Control(+ve) & $\begin{array}{c}c \\
1.34 \pm 0.16\end{array}$ & $\begin{array}{c}c \\
227.83 \pm 7.70\end{array}$ & $\begin{array}{c}\mathrm{d} \\
156.00 \pm 12.24\end{array}$ & $\begin{array}{c}\mathrm{d} \\
6.26 \pm 1.50\end{array}$ & $\begin{array}{c}c \\
29.56 \pm 2.68\end{array}$ & $\begin{array}{c}c \\
73.15 \pm 2.56\end{array}$ \\
\hline Omeprazole drug & $\begin{array}{c}\mathrm{b} \\
4.51 \pm 0.55\end{array}$ & $\begin{array}{c}\mathrm{b} \\
403.00 \pm 83.01\end{array}$ & $\begin{array}{c}\mathrm{b} \\
262.50 \pm 42.34\end{array}$ & $\begin{array}{c}\mathrm{b} \\
15.96 \pm 1.90\end{array}$ & $\begin{array}{c}\mathrm{a} \\
52.60 \pm 7.83\end{array}$ & $\begin{array}{c}\mathrm{b} \\
242.83 \pm 14.80\end{array}$ \\
\hline Virgin Coconut oil & $\begin{array}{c}\mathrm{a} \\
5.93 \pm 0.38\end{array}$ & $\begin{array}{c}\mathrm{b} \\
401.83 \pm 62.01\end{array}$ & $\begin{array}{c}\mathrm{b} \\
227.17 \pm 21.08\end{array}$ & $\begin{array}{c}c c \\
10.61 \pm 1.27\end{array}$ & $\begin{array}{c}\mathrm{b} \\
38.60 \pm 6.43\end{array}$ & $\begin{array}{c}\mathrm{a} \\
268.83 \pm 59.92\end{array}$ \\
\hline
\end{tabular}

Mean values in each column having different subscript $(\mathbf{a}, \mathbf{b}, \mathbf{c}, \mathbf{d}$, .)are significantly at $(\mathbf{P}<0.05)$.

Catalase (CAT) , Superoxide dismutase (SOD), Glutathione reduced (GSH) glutathione peroxidase (GPX), glutathione reductase (GSR) and glutathione-S-transferase (GST).

Table (5) showed significant increase in IL-6 and PG2 in ulcerative colitis rats group comparing with the negative control group, while CRP showed slightly increase. Virgin Coconut oil treated group (VCO) showed that significant lowering in CRP,IL-6 and PG2 levels compared with control (+ve) group. However appeared non-significant difference in CRP, IL-6 and PG2 levels in VCO group compared with omeprazole drug group. these studies indicate that the VCO group has a significant increase in anti-inflammatories.(Meng et al.,2019) reported that the Virgin coconut oil has antioxidant and anti-inflammatory properties that help control the regulation of prostaglandin synthesis and protect against damage by reactive oxygen species. The effect of VCO polyphenols on blood C-reactive protein (CRP) levels, interleukin-6 (IL-6), and nitric oxide (NO) has been demonstrated (Famurewaa et al., 2018). this is due mechanism behind the anti-inflammatory effect may be because of the ability of the VCO to reverse MTX-induced oxidative stress As indicated by the increase in activities of SOD, CAT, GPx, and GSH as well as an apparent decrease in MDA level and the ability of food polyphenols Modifiers of inflammatory cascades to avoid cause Pathogenesis and evidence of beneficial health effects.

Table 5. Some serum Anti-inflammation indicators of negative control (-ve) group, untreated ulcerative colitis rat (+ve) group and treated by Omeprazole drug or Virgin Coconut oil.

\begin{tabular}{lccc}
\hline \multicolumn{1}{c}{ Variable } & $\begin{array}{c}\text { CRP } \\
\text { Groups }\end{array}$ & $\begin{array}{c}\text { IL-6 } \\
(\mathbf{M g} / \mathbf{l}) \text { serum }\end{array}$ & $\begin{array}{c}\text { (Pg/ml) serum } \\
(\mathbf{M g} / \mathbf{l}) \text { serum }\end{array}$ \\
\hline Control (-ve) & $\mathrm{b}$ & $\mathrm{c}$ & $\mathrm{c}$ \\
& $0.67 \pm 0.15$ & $16.32 \pm 3.02$ & $14.34 \pm 1.06$ \\
\hline Control(+ve) & $\mathrm{a}$ & $\mathrm{a}$ & $\mathrm{a}$ \\
& $2.13 \pm 0.39$ & $81.22 \pm 6.93$ & $38.53 \pm 1.38$ \\
\hline Omeprazole & $\mathrm{b}$ & $\mathrm{b}$ & $\mathrm{b}$ \\
drug & $0.99 \pm 0.37$ & $55.93 \pm 3.35$ & $25.28 \pm 1.48$ \\
\hline Virgin Coconut & $\mathrm{b}$ & $\mathrm{b}$ & $\mathrm{b}$ \\
oil & $0.83 \pm 0.97$ & $55.76 \pm 7.12$ & $24.46 \pm 1.59$ \\
\hline
\end{tabular}

Mean values in each column having different subscript $(a, b, c$, and d)are significantly at $(\mathbf{P}<\mathbf{0 . 0 5})$.

C-reactive protein (CRP), interleulin-6 (IL-6) and prostaglandin (PG2). 


\section{REFERANCES}

Adeniyi, O. S.; Eru, E. U.; Oloche, J. J. and Vhirterhire, R. (2018): Poster Communications: Gastric ulcer healing effects of virgin coconut oil in experimental animals , Proc Physiol Soc 41, PCB116.

Aebi, H. (1984): Catalase in vitro, Methods in Enzymology, vol. 105, Academic Press ,pp. 121-126.

Artmitage, P. and Berry, G. (1987): Statistical methods in medical research, Blackwell Scientific Publications, Oxford, U.K., 1987. No. of pages: 559.

Arunima, S. and Rajamohan, T. (2013 ): Effect of virgin coconut oil enriched diet on the antioxidant status and paraoxonase 1 activity in ameliorating the oxidative stress in rats-A comparative study, Food and Function 4, 1402-1409.

Asagba, S. O.; Emudainohwo, J. O. T.; Ejebe, D. E.; Suru, M. S.; and OLISE, C. C. ( 2008): Comparative Effect of Coconut Oil and Palm Kernel Oil Supplemented Diets on $\mathrm{Na}+\mathrm{K}+$-Atpase Activity in the Liver, Kidney and Heart of Rats. Biomed Pharmacol J;1(1).

Assuncao, M. L.; Ferreira, H. S.; Santos A.F.; Cabral, C. R.; and Florencio, T. T. (2009): Effect of dietary coconut oil on the biochemical and anthropometric profiles of women presenting abdominal obesity. Lipids. 44(7), 593-601.

Awaad, S. A.; El-Meligy, M. R. and Soliman, A. G. (2013): Natural products in treatment of ulcerative colitis and peptic ulcer, Journal of Saudi Chemical Society, P 101-124.

Beutler, E.; Duron, O. and Kelly, M. B. (1963): Improved method for the determination of blood glutathione , J. Lab Clin. Med , 61:882-8 .

Biswas, K.; Bandyopadhyay, U.; Chattopadhyay, I.; Varadaraj, A.; Ali, E. and Anovel, B. R. (2003): antioxidant and antiapoptotic role of omeprazole drug durg to blockgastric ulcer through scavenging of hydroxyl radical. J Biol Chem, 278:10993-1001.

Calabrese L. H. and John, S. (2014): IL-6 biology: implications for clinical targeting in rheumatic disease. Nat Rev Rheumatol., 10(12):720-727.

Chandra, A.P. (2013): Effect of coconut oil on ulcerative colitis in the mouse model , Western Kentucky University, Department of Biology , Master of Science. Masters Theses \& Specialist Projects. Paper 1261.

Chapman, D. G.; Castillo, R. and Campbell, J. A. (1959): Evaluation of protein in foods. I.A method for the determination of protein efficiency ratios. Can. J. Biochem. Physiol. 37: 679-686.

Divina, D. B. and Keith, R. C. (2006): Virgin Coconut Oil Production Manual for Micro- And Village-Scale Processing. Thammada Press Co. Ltd, Bangkok. pp. 1-80.

Elife, E.; Cansel, T.; Burak, U. Z.; Arif, K.; Cemile, K.; Reyhan, B. and Ozlem, A. (2010): The Effects of Caffeic Acid Phenethyl Ester (CAPE) on Acetic Acid Induced Colitis in Rats. The New J Med. 27: 106-112.
Famurewa, A. C.; Folawiyo, A. M.; Enohnyaket, E. B.; Osu, S. O.; Sunday, I. A.; Obaje, S. G. and Famurewa, O. A. (2018): Beneficial role of virgin coconut oil supplementation against acute methotrexate chemotherapy-induced oxidative toxicity and inflammation in rats, Integrative Medicine Research, Volume 7, Issue 3, P :257-263.

Famurewaa, A. C.; Ejezieb, A. J.; Ejeziec-U, C. S.; Ikekpeazud, E. J. and Ejezied, F. E. (2018): Antioxidant and anti-inflammatory mechanisms of polyphenols isolated from virgin coconut oil attenuate cadmium-induced oxidative stressmediated nephrotoxicity and inflammation in rats., Journal of Applied Biomedicine, V (16), (I4), Nov , Pages 281-288.

Garg, M. L. and Blake, R. (1997): Cholesterol dynamics in rats fed diets containing either cariola oil or sunflower oil.,Nutr. Res. 3: 485-492.

Gastelluccio, C. ; Bolwell, G. ;Gerrish, C. and Rice-Evans, C.(1996): Differential distribution of ferulic acid to the major plasma constituents in relation to its potential as an antioxidant. Biochemical Journal, 316(2):691-694.

Goldberg, D.M. and Spooner, R. J. ( 1983): Assay of Glutathione Reductase. In: Bergmeyen, H.V., Ed., Methods of Enzymatic Analysis, 3rd Edition, Vol. 3, Verlog Chemie, Deerfiled Beach, 258-r 70.

Habig, W. and Jakoby, W. (1974 ): Colorimetric determination of glutathione S transferase. J. Biol. Chem 249: 7130-7139.

Ittiyavirah, S.P. and Shenika, M. S. (2014): Evaluation of antioxidant and anti-inflammatory activity of Omeprazole against experimentally induced colitis, Journal of Scientific and Innovative Research, (3): 352-356.

Itzkowitz, S. H. and Yio, X. (2004): Inflammation and cancer IV. Colorectal cancer in inflammatory bowel disease: the role of inflammation. Am J Physiol Gastrointest Liver Physiol, 287, G7-17.

Malaeb, S. and Spoke, C. (2020): The Glucose-Lowering Effects of Coconut Oil: A Case Report and Review of the Literature, Case Reports in Endocrinology, ID 8841781, 6 pages.

Marcia, F. C. J.; Marcus, V.O. B.; Rodrigo, M. P. L.; Andre, L. P.S. et al., (2020): Pharmacological Effects and Toxicogenetic Impacts of Omeprazole: Genomic Instability and Cancer, Oxidative Medicine and Cellular Longevity, 21 pages.

Marina, A. M.; Chem-Man, Y. B. and Amin, I. (2009): Virgin coconut oil: emerging functional food oil Trends .Food Sci Tech, 20, pp. 481-487.

Meng, j. ; Chen ,T.; Zhao, Y.; Lu, S.; Yu, H. and Chang ,Y. (2019) : Study of the mechanism of anti-ulcer effects of virgin coconut oil on gastric ulcer-induced rat model, Archives of Medical Science ,Sep;15(5):1329-1335.

Nishikimi, M.; Roa, N. A. and Yogi, K. (1972): Biochem. Bioph. Res. Common.,46, 849-854. 
NRC National Research Council (1992): (Recognition and Alleviation of Pain and Distress in Laboratory Animals, Washington DC, National Academy Press.

Odubanjo, O.V.; Oluwarotimi, A. E.; Ayeni, C.O. ; Akingbola, H. O.; and Olabisi, P.T. (2020): Fatty acid composition and antioxidant effect of coconut oil in Drosophila melanogaster ,Comparative Clinical Pathology ,(29):1147-1155.

Paglia, D. E. and Valentine, W. N. (1967): Studies on the quantitative and qualitative characterization of erthrocyte glutathione peroxidase. J. Lab. Clin. Med. 70:158-169.

Raeesi, M. ; Roozbahani, E. N. and Shomali, T. T. (2019): Gastro-protective effect of Biebersteinia multifida root hydro-methanolic extract in rats with ethanol-induced peptic ulcer., Aicenna J Phytomed410-418., (5):

Robert, A. (1979): Cytoprotection by prostaglandins. Gastroenterology 77:761-767.

Satoh, K. , (1978): Serum lipid peroxide in cerebrovascular disorders determined by a new colorimetric method, Clinica Chimica Acta, 15;90(1):37-43.

Septiana, A.T; Hidayah,D. (2010): Pengaruh MetodePen golahan Dan Jenis Pemanis Terhadap Aktivitas Antioksidan Minuman Dari Bubuk Mahkota Dewa. Conference : seminar nasional PERTETA. [online]. Tersedia di :https:// www .researchgate. net/ publication/ 288818120.
Seneviratne, K.N.; HapuarachchI, C. D. and Ekanayake, S. (2009): Comparison of the phenolicdependent antioxidant properties of coconut oil extracted under cold and hot conditions. Food Chem. 114, 14441449.

Srivastava, Y. ; Semwal, A. D.; Majumdar, A. and Yildiz, F. (2016): Quantitative and qualitative analysis of bioactive components present in virgin coconut oil. Cogent Food Agric 2(1): 1164929.

St-Onge, M. P.; Ross, R.; Parsons, W. D. and Jones, P. J. (2003): Medium-chain triglycerides increase energy expenditure and decrease adiposity in overweight men. Obes Res., 11(3): 395-402.

Vaishnavi, C. (1993): Immunology and Infectious Diseases. 3(6): 139-144.

Xavier, R. J. and Podolsky, D. K. (2007): Unraveling the pathogenesis of inflammatory bowel disease. Nature, 448, 427-434.

Zakaria, Z.; Somchit, M. ; Mat Jais, A. ; Teh ,L.; Salleh, M. and Long, K.( 2011): In vivo antinociceptive and anti-inflammatory activities of dried and fermented processed virgin coconut oil. Med Princ Pract., 20:231-236.

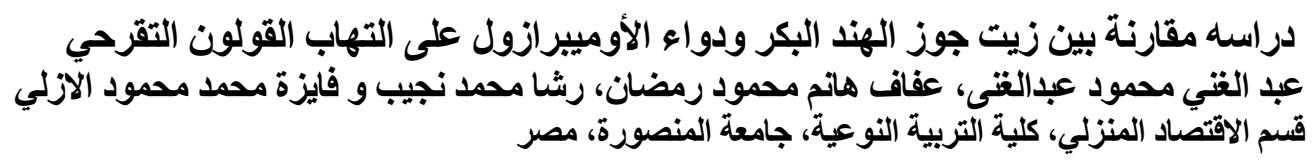

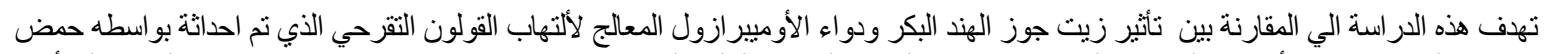

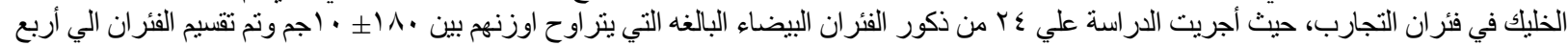

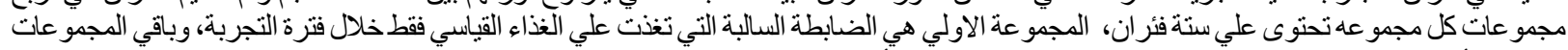

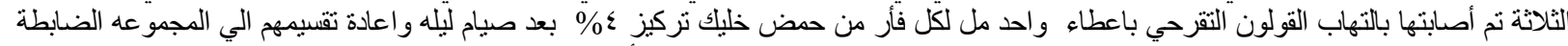

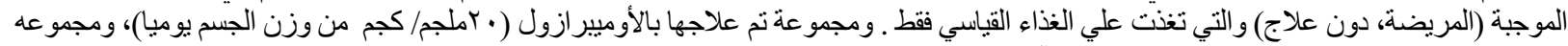

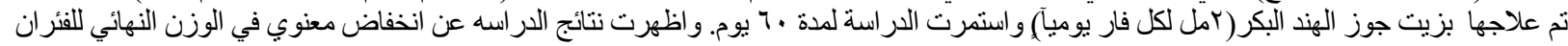

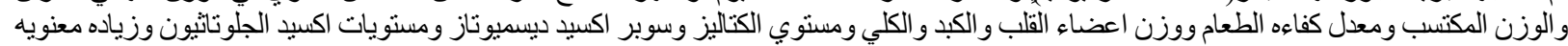

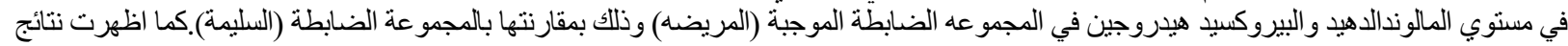

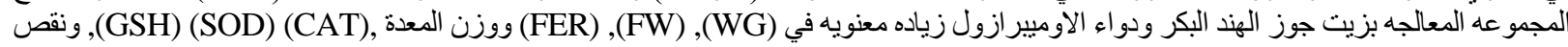

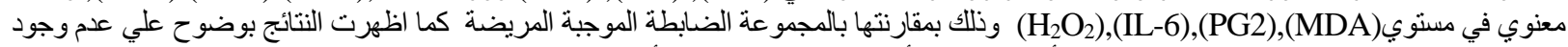

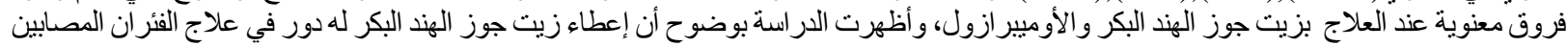

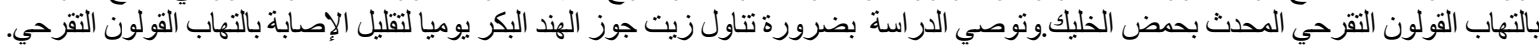
الكلمات الدالة: زيت جوز الهند البكر - التهاب القولون التقرحي - فئران التجارب - حمض الخليك. 